\title{
THE STUDY OF INFLUENCE OF ARONIA ADDITIVES ON FUNCTIONAL-TECHNOLOGICAL PROPERTIES OF WHEAT FLOUR
}

Yurii Korenets

Department of technology in a restaurant economy and hotel and restaurant business Donetsk National University of Economics and Trade named after Mykhailo Tugan-Baranovsky 16 Tramvaina str., Kryvyi Rih, Ukraine, 50005

yurii.korenets@gmail.com

\section{Iuliia Goriainova}

Department of technology in a restaurant economy and hotel and restaurant business Donetsk National University of Economics and Trade named after Mykhailo Tugan-Baranovsky 16 Tramvaina str., Kryvyi Rih, Ukraine, 50005

kaum@dkt.dn.ua

Radion Nykyforov

Department of technology in a restaurant economy and hotel and restaurant business Donetsk National University of Economics and Trade named after Mykhailo Tugan-Baranovsky 16 Tramvaina str., Kryvyi Rih, Ukraine, 50005

nikradion@yandex.ua

\section{Iryna Nazarenko}

Department of technology in a restaurant economy and hotel and restaurant business Donetsk National University of Economics and Trade named after Mykhailo Tugan-Baranovsky 16 Tramvaina str., Kryvyi Rih, Ukraine, 50005

nazarenko5555@mail.ru

Olga Simakova

Department of technology in a restaurant economy and hotel and restaurant business Donetsk National University of Economics and Trade named after Mykhailo Tugan-Baranovsky 16 Tramvaina str., Kryvyi Rih, Ukraine, 50005 simakovaolgaal@gmail.com

\footnotetext{
Abstract

The expedience of the use of aronia in technology of short dough products as a source of vitamins, mineral, pectin substances, phenol compounds, easily assimilated sugars, organic acids and so on was substantiated. To study the influence of aronia additives on the main receipt component of short dough (wheat flour) there was elaborated an algorithm of the study that includes theoretical analysis and physical-chemical experiment. The expedience of introduction of aronia as a powder directly into wheat flour was theoretically grounded. The methods of estimation of the content of polyphenol compounds, influence of aronia additives on amylolytic and proteolytic activity of wheat flour, its sugar-creating ability, were selected. The methods of experiment planning and mathematical processing of experimental data were realized using computer program MS Excel 972003.

In was established, that the aronia additive weakens the gluten of wheat flour and prevents the swelling of gluten proteins. It positively influences the process of short dough formation and provides a possibility of its storage during the long time until baking. The use of aronia additives in technology of short dough products allows not only raise their food value but also improve the quality of short dough.

Keywords: aronia, short dough, wheat flour, anthocyanins, amylolytic activity.
}

DOI: $10.21303 / 2504-5695.2017 .00299$

(C) Yurii Korenets, Iuliia Goriainova, Radion Nykyforov, Iryna Nazarenko, Olga Simakova

\section{Introduction}

The unconventional vegetable raw material is widely used for improving the food value of flour confectionary [1]. It is prospective to use aronia as a source of vitamins, mineral substances, phenol compounds and so on [2]. 
The studies in vitro and in vivo testify that the polyphenols of plants, including anthocyanins play the important role in protection of human health [3]. It was established, that just aronia is characterized with high content of anthocyanins $\left(4341 \mathrm{mg} / \mathrm{kg}^{-1}\right)$ and their high antioxidant activity [4]. Due to the high content of anthocyanins aronia fruits positively influence the cardio-vascular system activity, digestive organs and so on [5].

It is expedient to use aronia as a powder. The anthocyanins of aronia fruits were released from dried raw material by extraction by the solutions of hydrochloric acid in water or ethanol with $\omega=1 \%$ [6]. Their content in water and alcoholic extract is almost equal $-1,98$ and 2,12 \% respectively. At the same time it is well-known, that the general content of bioflavonoids in fruits is near $5 \%$. It is proved [7] that at using ultrasound the significant acceleration of production process and increase of the main product output comparing with other methods are observed.

The studies, directed on the increase of food value of short dough products adding aronia directly to the wheat flour are practically absent. Such method of the use of this unconventional raw material can open new ways of improvement of short dough products quality.

The aim of the work is to study the influence of physiologically active compounds of aronia additives (AA) on functional-technological properties of wheat flour.

For attaining the set aim it is necessary to solve the following problems: to study AA influence on the state of protein complex of wheat flour; to determine AA influence of amylolytic activity of wheat flour.

\section{Materials and Methods}

The powder from aronia dry fruits was gotten by their refinement using micro-shredder of tissues RT-1 (Fig. 1, a), produced by PQG “GRANAT”, Saint Petersburg city, (Russia). The refinement was realized by knives, which rotation speed is $4000 \mathrm{turn} / \mathrm{min}$. The drying of aronia fruits was carried out at temperature $80 \ldots 90^{\circ} \mathrm{C}$ during $2 \ldots 3$ hours up to the constant mass of sample. The alcoholic and water extracts from aronia fruits were prepared both according to well-known methods [8], and using ultrasound technologies (UST) [7].

For estimating the content of polyphenol compounds [9] the sample of well-refined vegetable raw material with mass $2 \mathrm{~g}$ was put in chemical glass, $70 \mathrm{ml}$ of distilled water were added and it was heated up to $80^{\circ} \mathrm{C}[10]$.

The cooled mixture was quantitatively transferred in measuring flask with volume $250 \mathrm{ml}$, glass was rinsed $2 . . .3$ times with distilled water and the content of flask was brought to the mark. The gotten mixture was left for $30 \mathrm{~min}$, at that time it was energetically shaken 5-6 times then filtered through paper folded filter. $10 \mathrm{ml}$ of filtrate was measured in big porcelain cup with volume $11,750 \mathrm{ml}$ of distilled water, $25 \mathrm{ml}$ of indigo carmine solution and $10 \mathrm{ml}$ of diluted $\mathrm{H}_{2} \mathrm{SO}_{4}(1: 4)$ were added. The mixture was titrated by $0,05 \mathrm{~N}$ solution of $\mathrm{KMnO}_{4}$, being energetically mixed by glassy bacillus. Titration was realized with speed 1 drop a second up to faintly rose color. The color of mixture in cup gradually changes: from blue it becomes deep-green, green-yellow then golden-yellow. For correcting data for other oxidized components of material, there was realized the control experience, during which the polyphenols were eliminated by their adsorption from extract by activated carbon. The content of phenol substances was calculated according to the formula (1):

$$
\mathrm{X}=\frac{(\mathrm{a}-\mathrm{B}) \cdot 0,004157 \cdot \mathrm{V} \cdot 100}{\mathrm{G} \cdot 2 \cdot \mathrm{V}_{1}}
$$

where $\mathrm{X}$ - the content of phenol compounds in sample, \%; $(\mathrm{a}-\mathrm{c})$ - the difference between volumes of $0,05 \mathrm{~N}$ solution of $\mathrm{KMnO}_{4}$, spent for titration in working and control experiences, ml; 0,004157 - coefficient of recalculation of the result of titration in phenol compounds $(1 \mathrm{ml}$ of $0,1 \mathrm{~N}$ solution of $\mathrm{KMnO}_{4}$ corresponds to $0,004157 \mathrm{~g}$ of phenols, for example, tannin); $\mathrm{V}$ - general volume of extraction, $\mathrm{ml} ; \mathrm{V}_{1}$ - volume of filtrate, taken for analysis, $\mathrm{ml} ; \mathrm{G}$ - sample of studied product, $\mathrm{g}$.

The estimation of summary activity of amylases of aronia fruits was realized by Bendelow method. For that $2 \mathrm{ml}$ of distilled water and $3 \mathrm{ml}$ of citrate buffer were added to $5 \mathrm{ml}$ of enzyme extract $(\omega=5 \%)$. To prepare this reagent $21,008 \mathrm{~g}$ of citric acid and $200 \mathrm{ml}$ of $1 \mathrm{~N}$ solution of $\mathrm{NaOH}$ 
were mixed in measuring flask with volume 11 , were added with distilled water up to the mark. $700 \mathrm{ml}$ of this solution were mixed with $300 \mathrm{ml}$ of $0,1 \mathrm{~N}$ solution of $\mathrm{NaOH}$. Then $10 \mathrm{ml}$ of starch solution $(\omega=2 \%)$, heated to $40{ }^{\circ} \mathrm{C}$, were added to reactive mixture. The mixture was heated at this temperature during 15 minutes, the sample was taken away and analyzed for maltose content by well-known methodology using Felling reagent [9].

The estimation of sugar-creating ability of flour at AA was carried out as following:

- $10 \mathrm{~g}$ of flour were weighed $(9,5 \mathrm{~g}$ of flour and $0,5 \mathrm{~g}$ of additive are weighed at using additives in dry form);

- it was put in dry measuring flask for $100 \mathrm{ml}$;

- kept on water bath at temperature $27^{\circ} \mathrm{C}$ during 15 minutes.

Such methodology of estimation of sugar-creating ability of the flour is realized by the quantity of milligrams of maltose, created from $10 \mathrm{~g}$ of flour for 1 hour of keeping from $50 \mathrm{~cm}^{3}$ of water at temperature $27^{\circ} \mathrm{C}$.

The technique of estimation $-10 \mathrm{~g}$ of flour, weighed with error no more than $0,05 \mathrm{~g}$, is quantitatively transferred in dry measuring flask with capacity $100 \mathrm{~cm}^{3}$. The flask with sample is placed on water bath or thermostat with temperature $27^{\circ} \mathrm{C}$ for $15 \mathrm{~min}$ for hitting. Then $50 \mathrm{~cm}^{3}$ of distilled water with temperature $27^{\circ} \mathrm{C}$ are added in flask by pipette, fast and accurately mixed up to homogenous state (without clots) and thermostated at the same temperature during 1 hour, shaking mixture each $15 \mathrm{~min}$. In this period hydrolysis of flour starch takes place under influence of own amylolytic enzymes.

After 1 hour, inactivation of enzymes is realized, adding in flask $15 \mathrm{~cm}^{3}$ of $15 \% \mathrm{ZnS}_{4}$ and $15 \mathrm{~cm}^{3}$ of $1 \mathrm{~N}$ solution of $\mathrm{NaOH}$ by cylinder, continuously stirring mixture. Then it is added with water to the mark, mixed during $3 \mathrm{~min}$, kept for 3-5 min and filtered through the paper folded filter in dry flask.

The amount of created sugar is estimated in transparent filtrate using different methods.

For estimating proteolytic activity of the raw material $5 \mathrm{ml}$ of additive extract $(\omega=5 \%)$ were added to $20 \mathrm{ml}$ of gelatin solution $(\omega=2 \%)$, reactive mixture was kept in thermostat at temperature $25{ }^{\circ} \mathrm{C}$ during 2 hours [11].

After that the reactive mixture was filtered and kinematic coefficient of filtrate viscosity was found by capillary viscosimeter VTL-2 (“Oilchemigroup, LTD, laboratory equipment, Kyiv city, Ukraine) with capillary diameter 0,56 in water thermostat (Fig. 1, b) [12].

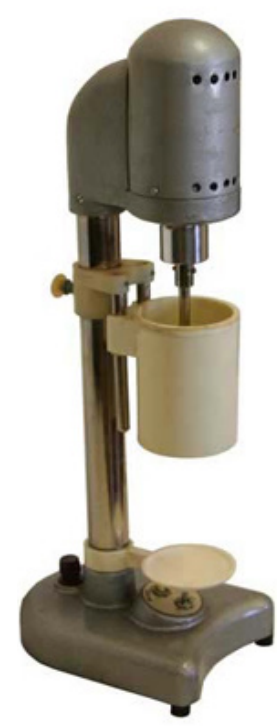

$a$

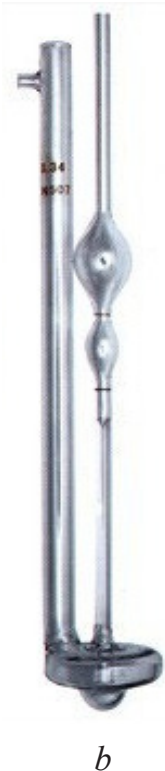

$b$

Fig. 1. The types of equipment, used during the study: $a$ - micro-shredder of tissues RT-1; $b$ - viscosimeter VTL-2 with capillary diameter 0,56 in water thermostat 
Thermostating of the solutions was carried out with exactness up to $+0,1^{\circ} \mathrm{C}$. The system was kept no less than 15 min before starting measuring. Before experiment the solutions were filtered through Shotta filter. The kinematic coefficient of viscosity was calculated according to the formula (2):

$$
\eta=\mathrm{t}_{\text {solution }} / \mathrm{t}_{\text {solvent }}
$$

where $\eta$ - kinematic coefficient of viscosity; $t_{\text {solution }}$ - time of solution outflow, $s$; $t_{\text {solvent }}$ - time of solvent outflow, s.

The methods of experiment planning and mathematical processing of experimental data were realized using computer program MS Excel 97 2003. For statistical reliability all experiments were fivefold repeated.

\section{1. Experimental procedure}

AA influence on protein-proteinase complex of wheat flour was estimated. To reveal this influence the qualitative characteristics of gluten were studied. The one was washed from the dough, prepared of extra wheat flour (TM “Chutorok", Ukraine) with AA in quantity $5 \%$ of wheat mass. Another - from the dough, prepared on water extract of aronia with mass share $5 \%$. The results of AA influence on the quality of wheat flour gluten are presented in the Table 1.

Table 1

The influence of aronia additives on the quality of wheat flour gluten

\begin{tabular}{ccccc}
\hline $\begin{array}{c}\text { Studied sample of } \\
\text { dough }\end{array}$ & $\begin{array}{c}\text { Output of } \\
\text { raw gluten, } \%\end{array}$ & $\begin{array}{c}\text { Output of } \\
\text { dry gluten, } \%\end{array}$ & $\begin{array}{c}\text { Gluten ability to } \\
\text { stretching, cm }\end{array}$ & $\begin{array}{c}\text { Gluten ability to } \\
\text { spreading, mm }\end{array}$ \\
\hline Without additive & $34,2 \pm 2,4$ & $14,0 \pm 0,8$ & $3,5 \pm 0,2$ & $41,0 \pm 3,3$ \\
With AA & $33,4 \pm 2,3$ & $14,9 \pm 0,6$ & $4,3 \pm 0,2$ & $45,0 \pm 3,2$ \\
On AA water extract & $32,0 \pm 1,9$ & $15,5 \pm 1,1$ & $3,8 \pm 0,2$ & $42,0 \pm 3,4$
\end{tabular}

For quantitative assessment of acidic properties of compound there was carried out electrometric titration of water extract of aronia by $0,01 \mathrm{~N}$ solution of sodium hydroxide, which results are presented on the Fig. 2.

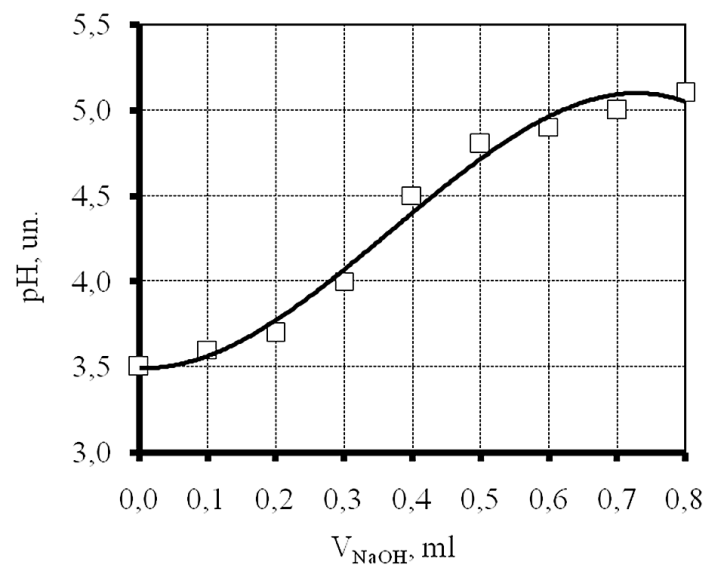

Fig. 2. Electrometric titration of water extract of aronia by $0,01 \mathrm{~N}$ solution of $\mathrm{NaOH}$

At the assessment of acidic properties of anthocyanins $\mathrm{pH}$ was considered as its value in the point of semi-neutralization. The data of Fig. 2 testify that it is 3,7. This cipher characterizes the aronia anthocyanins as rather strong acids. 
The complicated complex of different chemical substances of additive probably blocks the effect of flour proteolytic enzymes acting as their inhibitors. To prove the process of inhibition of proteolytic enzymes of wheat flour, the process of hydrolysis of wheat flour gluten proteins was studied under the effect of its own proteolytic enzymes and with AA. It is well-known, that proteolytic activity of enzymes can be estimated also by the character of protein substances disintegration and by the quantity of created products of hydrolysis that is free amino acids [13]. The quantity of created amino acids is estimated by the content of nitrogen of amino groups, analyzed by formol or electrometric titration. The study of autolytic activity of wheat flour was carried out without additives and with AA (its water extract with $\omega=5 \%$ and dry powder in concentration $5 \%$ relative to the flour mass). The quantity of amino acids, created as a result of enzymatic hydrolysis was estimated by formol titration. The results of the study of AA influence on the content of free amino acids in the products of wheat flour autolysis are presented in the Table 2.

Table 2

The influence of aronia additives on free amino acids content in the products of wheat flour autolysis

It was established, that AA doesn't only manifest any proteolytic activity but also rather effectively decelerate the process of protein molecules disintegration under the effect of proteolytic enzymes of wheat flour.

Such active process of inhibition of proteolytic enzymes of wheat flour allows presume that other hydrolytic enzymes of flour will be also paralyzed by AA effect. That is why there was studied the influence of aronia additive of sugar-creating ability of wheat flour that is the activity of its enzymes-amylases. The process was controlled by estimation of maltose quantity in reactive mixture. The results of the study of AA influence on amylolytic activity of wheat flour are presented on the Table 3.

The mechanism of inhibition of enzymes-amylases by aronia preparations can by interpreted in different ways. Optimal pH effect of enzymes-amylases is 5,6 [9], but acid extracts of aronia fruits decrease $\mathrm{pH}$ of the medium and in such a way decrease the amylolytic activity of enzymes. To verify this mechanism the amylolytic activity of wheat flour was estimated at presence of aronia preparations. $\mathrm{pH}$ of reactive medium was kept within 5,5..6,0. The mixture was neutralized by the solution of sodium hydrocarbonate. The received parameters of maltose content in reactive mixture are presented in the Table 3 .

Obviously, there is an interaction of metal cation with two different molecules of anthocyanidins with creation of compounds with twice more molecular mass. As a result of this process, the cations of metals-activators are removed from reactive mixture and become inaccessible for activation of enzyme-substrate complex. That, in its turn, leads to inhibition of hydrolytic processes in wheat flour (the effect of enzymes-amylases of wheat flour is inhibited by $29 . . .82 \%$ ).

To verify this suggestion the amylolytic activity of wheat flour was estimated at presence of acknowledged amylases activator $-\mathrm{Ca}^{2+}$ cation. The results of the study of AA influence at presence of $\mathrm{Ca}^{2+}$ cation on amylolytic activity of wheat flour are given in the Table 4 .

It was established, that AA at presence of calcium ions practically completely paralyzes the effect of wheat flour enzymes, bounding all ions of reactive mixture in strong complex compounds. 
Table 3

The influence of aronia additives on amylolytic activity of wheat flour

\begin{tabular}{|c|c|c|}
\hline Substrate & $\begin{array}{l}\text { Maltose value, } \\
\% \text { of maltose }\end{array}$ & $\begin{array}{c}\text { Maltose value, } \\
\% \text { of maltose } \\
(\mathrm{pH} \text { of medium }-5,5 . .6,0)\end{array}$ \\
\hline Water suspension of wheat flour & $4,10 \pm 0,37$ & $4,10 \pm 0,37$ \\
\hline Suspension of wheat flour in aronia water extract & $0,72 \pm 0,04$ & $0,93 \pm 0,07$ \\
\hline Water extraction of wheat flour with AA & $2,91 \pm 0,17$ & $3,21 \pm 0,13$ \\
\hline Suspension of wheat flour in aronia fresh juice & - & - \\
\hline
\end{tabular}

Table 4

The Aronia additives influence at presence of $\mathrm{Ca}^{2+}$ cation $\left(\mathrm{C}_{\mathrm{Ca}}^{2+}=0,1 \%\right)$ on amylolytic activity of wheat flour

\begin{tabular}{cc} 
Substrate & Maltose value, \% of maltose \\
\hline Water suspension of wheat flour $+\mathrm{Ca}^{2+}$ & $8,56 \pm 0,34$ \\
Suspension of wheat flour in aronia water extract $+\mathrm{Ca}^{2+}$ & $1,53 \pm 0,09$ \\
Water extract of wheat flour with $\mathrm{AA}+\mathrm{Ca}^{2+}$ & $3,94 \pm 0,28$
\end{tabular}

\section{Results}

It was established (Table 1), that AA weakens the flour gluten (gluten ability to stretching increases by $9 . .23 \%$ ). It is a positive factor for short dough formation. It becomes more plastic and doesn't need the starch, often added to the receipt just for increasing the receipt mixture plasticity. Due to the presence of phenol compounds of hydroxyl groups in molecules and due to the features of electronic structure of benzene ring, they have unique properties. The main one is an ability to reverse oxidation that is to the transfer of phenol forms in quinoid forms. That is why practically all phenol substances have brightly expressed anti-oxidant activity $[14,15]$.

The powder of aronia has more active influence on this process comparing with extract that can be explained by more polyphenol concentration in dough semi-finished product at using dry preparation. The raw gluten output at using AA decreases by 3...6 \%. It testifies to the decrease of hydrogen bonds in protein macromolecules and partial loss of ability to bound water and to keep it.

AA use prevents the swelling of wheat flour gluten proteins due the decrease of ability to keep water. It allows increase the duration of short semi-finished product manufacturing and provides a possibility of its storage during the long time till baking.

It was established (Table 3), that aronia preparations are the strong inhibitors of enzymes-amylases of wheat flour. At that the inhibition regularity is quite other than in case with enzymes-proteinases of flour. The water extract from fruits inhibits amylases significantly stronger than the powder of dry fruits, in the case of proteolytic enzymes it was vice versa.

The gotten data practically coincide with earlier ones, received at using aronia preparations without neutralization of their acidic properties (Table 3). There was set practically invisible but stable growth of maltose value that can be explained by acidic inhibition of enzymes, but the contri- 
stable growth of maltose value that can be explained by acidic inhibition of enzymes, but the contribution of such inhibition way is absolutely insignificant. It is proved, that the change of $\mathrm{pH}$ medium practically doesn't influence the elements of aronia compounds structure that are responsible for enzymes inhibition.

The results of the study of AA influence at presence of $\mathrm{Ca}^{2+}$ cation of amylolytic activity of wheat flour (Table 4) testify to more high degree of amylases inhibition by the extract or juice of aronia comparing with powder of dry fruits. It can be explained by the fact that water-soluble phenol compounds of aronia in reactive mixture at once begin to interact with metal cations that are present there and bound them in stable complexes. At using the dry powder of aronia, certain time is necessary to extraction of polyphenol compounds by the water that makes them accessible for reaction with metal cations. During this time the flour amylases can partially realize their hydrolytic function.

The received experimental data allows manage the hydrolytic processes in dough semi-finished product.

Thus, AA usage in technology of short dough products favors not only the increase of their food value but also allows increase the short dough quality.

\section{Conclusions}

1. The influence of physiologically active AA compounds on the wheat flour gluten quality was studied. It was established, that AA as a powder and water extract weakens the flour gluten that is a positive factor for short dough formation. The gluten ability to stretching increases by $9 \ldots 23 \%$. The dough becomes more plastic. It doesn't need starch, often added to the receipts just for increasing the receipt mixture plasticity.

It was established, that AA polyphenol substances prevent the swelling of wheat flour gluten proteins due to the decrease of ability to keep water that provides a possibility of its storage during the long time till baking.

2. The higher degree of amylases inhibition in wheat flour by extract of aronia fruits or its juice comparing with powder of dry fruits was revealed. The water-soluble aronia phenol compounds in reactive mixture begin to interact with metal cations that are present there and bound them in strong complexes. The received experimental data allow not only manage hydrolytic processes in dough semi-finished product but also widen the possibilities of using wheat flour of lower grades, neutralizing the harmful enzyme effect in it.

The prospects of further research are the study of AA influence on the state of fatty component of short dough, substantiation of AA rational concentration to wheat flour and elaboration of technology of short dough with AA.

\section{References}

[1] Matveeva, T. V., Koriachkina, S. Ya. (2016). Muchnye konditerskie izdeliia funktsionalnogo naznacheniia. Nauchnye osnovy, tekhnologii, retseptury. St. Petersburg: GIORD, 360.

[2] Simakhina, G., Naumenko, N., Khalapsina, S. (2012). Biological value of aronia berries. Ukrainian food journal, 1, 8-11.

[3] Poracova, J., Sedlak, V., Posivakova, T., Mirutenko, V., Gruova, D., Mydlarova-Blascakova, M., Kotosova, J. (2013). Measurement of antioxidant activity in chokeberry (Aronia melanocarpa WILD.) and black elderberry (Sambucus nigra L.) using the DPPH method. Materialy vtoroi Mezhdunarodnoi nauchno-prakticheskoi internet-konferentsii "Lekarstvennoe rastenievodtvo: ot opyta proshlogo k sovremennym tekhnologiiam”. Poltava, 132-136.

[4] Jakobek, L., Seruga, M., Medvidovic-Kosanovic, M., Novak, I. (2007). Antioxidant Activity and Polyphenols of Aronia in Comparison to other Berry Species. Agriculturae Conspectus Scientificus, 72 (4), 301-306.

[5] Olas, B., Wachowicz, B., Nowak, P., Kedzierska, M., Tomczak, A., Stochmal, A., Oleszek, W., Jeziorski, A., Piekarski, J. (2008). Studies on antioxidant properties of polyphenol - rich 
extract from berries of Aronia melanocarpa in blood platelets. Journal of Physiology and Pharmacology, 59 (4), 823-835.

[6] Mariichuk, R., Feier, J., Eliashova, A., Grulova, D., Shalamon, I. (2014). Ekstraktsciia antotsianiniv iz roslynnoi syrovyny. Naukovij visnik Uzgorods'kogo universitetu. Seria Himia, 2 (32), 35-37.

[7] Hmelev, V. N., Slivin, A. N., Barsukov, R. V., Tsyganok, S. N., Shalunov, A. V. (2010). Primenenie ultrazvuka vysokoi intensivnosti v promyshlennosti. Biisk: Altai State University, 203.

[8] Melnychuk, D. O., Vovkotrub, M. P., Melnikova, N. M., Melnychuk, S. D., Bukhtiiarov, V. K., Yakubovych, T. M., Krotenko, V. V. (2010). Praktykum z organichnoi ta biologichnoi himii. Kyiv, 300.

[9] Krasilnikova, L. O., Avksentieva, O. O., Zhmurko, V. V. (2007). Biohimiia roslyn. Kharkiv: Koloryt, 191.

[10] Ermakov, A. I. (Ed.) (1987). Metody biohimicheskogo issledovanii rastenii. Leningrad: Agropromizdat, 430 .

[11] Aivazov, B. V. (1973). Praktikum po himii poverhnostnyh iavlenii i adsorbtsii. Moscow: Vysshaia shkola, 206.

[12] Starosta, V. I., Yanchuk, O. M. (2014). Koloidna himiia. Praktykum. Lutsk: Lesya Ukrainka Eastern European National University, 360.

[13] Prosekov, A. Yu., Ulrikh, E. V., Noskova, S. Yu., Budrik, V. G., Botina, S. G., Agarkova, E. Yu., Melnikova, E. I. (2013). Poluchenie fermentnykh gidrolizatov belkov molochnoi syvorotki s ispolzovaniem proteoleticheskikh fermentov. Fundamentalnye issledovaniia, 6, 1089-1093.

[14] Katalinic, V., Milos, M., Kulisic, T., Jukic, M. (2006). Screening of 70 medicinal plant extracts for antioxidant capacity and total phenols. Food Chemistry, 94 (4), 550-557. doi: 10.1016/ j.foodchem.2004.12.004

[15] Laguta, I. V., Stavinskaya, O. N., Dzyuba, O. I., Ivannikov, R. V. (2015). Analysis of antioxidant properties of plants extracts. Reports of the National Academy of Sciences of Ukraine, 5, 130-137. doi: 10.15407/dopovidi2015.05.130 